\title{
Remittances and Financial Inclusion in Development
}

\author{
Helen S. Toxopeus and Robert Lensink*
}

August 2007

\begin{abstract}
In this paper we focus on the relationship between remittance inflows and financial inclusion in developing countries. We present single equation estimates on remittances and financial inclusion, and system estimates in which economic growth is explained by e.g., financial inclusion, and financial inclusion by, e.g., remittances inflows. These regressions clearly confirm our main hypothesis that remittances have a development impact through their effect on financial inclusion. Overall, our paper indicates the importance of studying the effects of remittances in developing countries. Remittances, in terms of size, are not only one of the main capital inflows in developing countries, often even more substantial than ODA, but they also appear to have a robust positive effect on economic growth.
\end{abstract}

Keywords: capital flows, remittances, finance

JEL classification: F24, G21

Copyright (C) UNU-WIDER 2007

* Faculty of Economics, University of Groningen, Groningen, the Netherlands. email: B.W.Lensink@rug.nl (for corresponding author); hstoxopeus@hotmail.com (for Helen Toxopeus)

This study is a revised version of the paper presented at the 16-17 June 2006 WIDER development conference on 'Aid: Principles, Policies, and Performance', directed by George Mavrotas.

UNU-WIDER gratefully acknowledges the financial contribution to the conference by the Finnish Ministry for Foreign Affairs.

UNU-WIDER also acknowledges the financial contributions to the research programme by the governments of Denmark (Royal Ministry of Foreign Affairs), Finland (Ministry for Foreign Affairs) Norway (Royal Ministry of Foreign Affairs), Sweden (Swedish International Development Cooperation Agency_Sida) and the United Kingdom (Department for International Development). 


\section{Acknowledgements}

We would like to thank Niels Hermes for constructive comments on an earlier version of this paper.

\section{Acronyms}

FDI foreign direct investments

IRnet international remittance network

LAC Latin America and Caribbean countries

ODA official development assistance

The World Institute for Development Economics Research (WIDER) was established by the United Nations University (UNU) as its first research and training centre and started work in Helsinki, Finland in 1985. The Institute undertakes applied research and policy analysis on structural changes affecting the developing and transitional economies, provides a forum for the advocacy of policies leading to robust, equitable and environmentally sustainable growth, and promotes capacity strengthening and training in the field of economic and social policy making. Work is carried out by staff researchers and visiting scholars in Helsinki and through networks of collaborating scholars and institutions around the world.

www.wider.unu.edu

publications@wider.unu.edu

UNU World Institute for Development Economics Research (UNU-WIDER)

Katajanokanlaituri 6 B, 00160 Helsinki, Finland

Typescript prepared by Liisa Roponen at UNU-WIDER

The views expressed in this publication are those of the author(s). Publication does not imply endorsement by the Institute or the United Nations University, nor by the programme/project sponsors, of any of the views expressed. 


\section{Introduction}

Each year millions of migrants send money earned abroad back to their country of origin. They participate in globalization by engaging in arbitrage in international labour markets, creating family bonds and obligations across countries. The development impact of migration and the ensuing international remittance flow have become increasingly the subject of research and policy discussions, once the vast scale of international 'people and money flows' became apparent. It is no longer uncommon for remittance inflows to constitute between 5-10 per cent of total GDP in (small) developing countries (World Bank 2005b). Remittance inflows surpass official development flows in middle-income countries, and foreign direct investment in lowincome countries. For 2005, the World Bank estimates the total flows to equal US\$250 billion (including informal flows). This trend is unlikely to reverse in the medium to long term. Migration is expected to continue and costs of remitting are falling, providing a lower threshold for migration. The World Bank (2005c: 92-3) expects that remittance flows will continue to grow at an annual rate of 7-8 per cent, similar to the growth rates of the 1990s (ibid).

The effects of this large-scale movement of capital are many, both positive and negative (for a full discussion, see World Bank 2005c: 99-105). On the downside, a large inflow of remittances may lead to currency appreciation, thereby lowering competitiveness of export products (World Bank 2005c: 104). Some also argue that the work effort of remittance recipients may decrease, thus dampening growth (Chami, Fullenkamp and Jahjah 2005). On the positive side, remittance inflows increase capital availability for consumption in the receiving countries, and can create in the local economies multiplier effects on GDP, job creation, consumption, income and investment (Stahl and Arnold 1986; De Vasconcelos 2005). Remittances also supply foreign exchange, complementing national savings and providing funding for investment, notably for small-scale projects, hence providing finance for output growth (Solimano 2003). Bugamelli and Paternò (viewed on multiple occasions) (2005) show that a large flow of remittances into a country can help reduce the probability of current account reversals, and thus lower the chance of a financial crisis. Furthermore, remittances are a person-toperson flow of money without government intervention, often delivered directly to the lower-income segment of a country. They can therefore stimulate development without increasing debt or administrative burden. Remittances are also supposed to improve financial inclusion by providing affordable financial services within the formal financial system to those who tend to be excluded. Remittances may therefore play a crucial role in the wider issue of access to finance.

There is now ample evidence that financial development in general, and banking development in particular, has a positive effect on economic growth (see, e.g., Levine 2003). However, while available literature suggests that remittances may stimulate economic growth, for example, through improved financial inclusion, there is a lack of empirical studies to confirm this hypothesis. In this paper, we take up the challenge to empirically assess the impact of remittance inflows on financial inclusion. More specifically, this paper is the first to demonstrate the effect of remittance inflows on financial access and usage for a cross-country group of developing countries. We also provide new empirical evidence on the growth effects of remittances to developing countries through improvement of financial inclusion. 
This paper continues as follows. In the next section we describe trends in remittance flows. Next, we present arguments for a causal effect of remittance inflow on financial inclusion, followed by preliminary evidence of this relationship. In section 4 we discuss the sampling and research design of the methodology. This is followed in section 5 by the data analysis. The paper concludes with a summary and some recommendations.

\section{Trends in remittances}

The importance of workers' remittances is clearly shown by Figure 1. This figure indicates that since 1997, remittance flows to the entire group of developing countries surpass the inflow of official development assistance (ODA). However, foreign direct investments (FDI) are still the most important inflow for the entire group of developing countries. The same holds for such country groups as the upper middle-income countries (Figure 2), the lower middle-income countries (Figure 3) and the regions of East Asia and the Pacific (Figure 5), Latin America (Figure 6), and Europe and Central Asia (Figure 7).

FDI, ODA and remittance inflows

Figure 1: Low- and middle-income countries

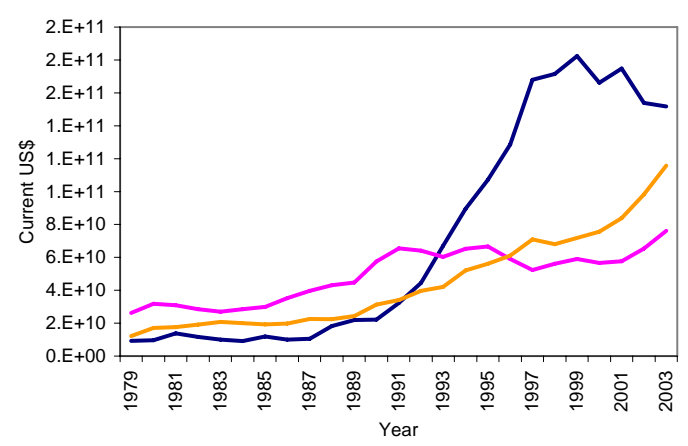

- FDI, net inflows (BoP, current US\$)

— ODA \& official aid (current US\$)

Worker remittances \& employee compensation, received (US\$)

Source: World Bank (2005b)

Figure 3: Lower middle-income countries

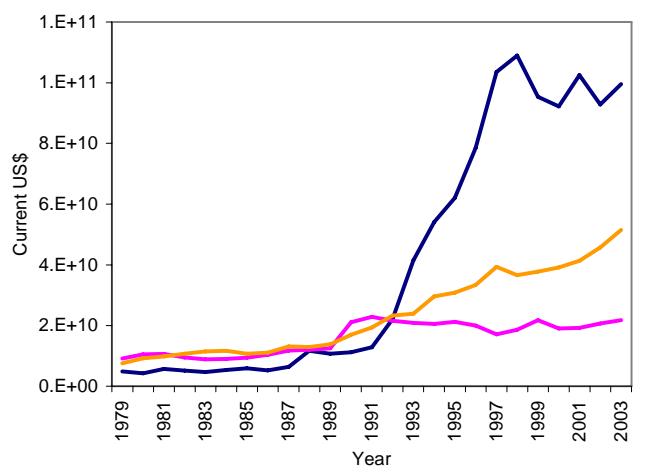

—FDI, net inflows (BoP, current US\$)

- ODA and official aid (current US\$)

Worker remittances \& employee compensation received (US\$)
Figure 2: Upper-middle income countries

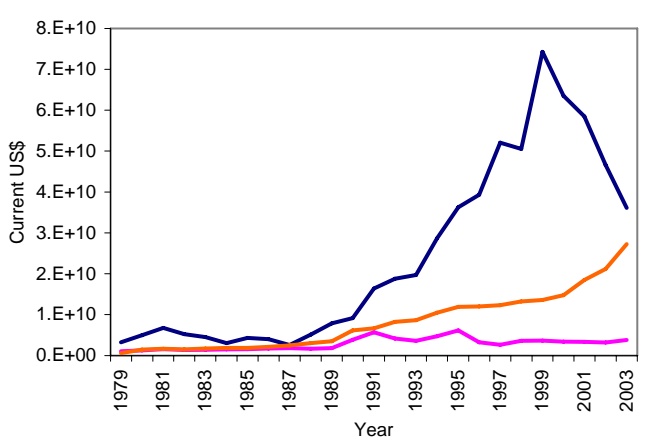

—FDI, net inflows (BoP, current US\$)

ODA and official aid (current US\$)

Worker remittances \& employee compensation, received (US\$)

Source: World Bank (2005a and 2005b)

Figure 4: Low-income countries

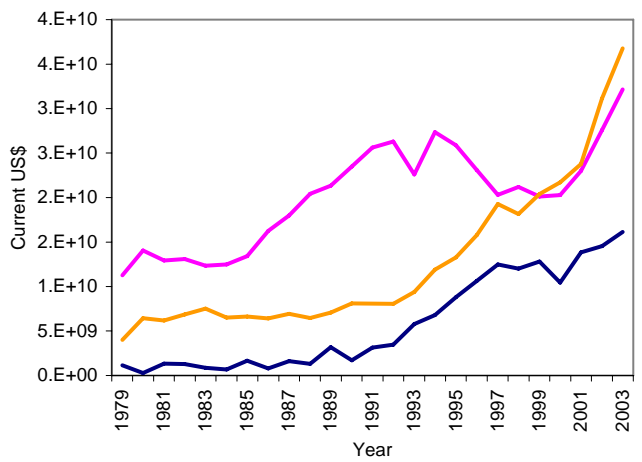

-FDI, net inflows (BoP, current US\$)

- ODA \& official aid (current US\$)

Worker remittances \& employee compensation, received (US\$)

Source: World Bank (2005a and 2005b) 
Figure 5: East Asia and Pacific region

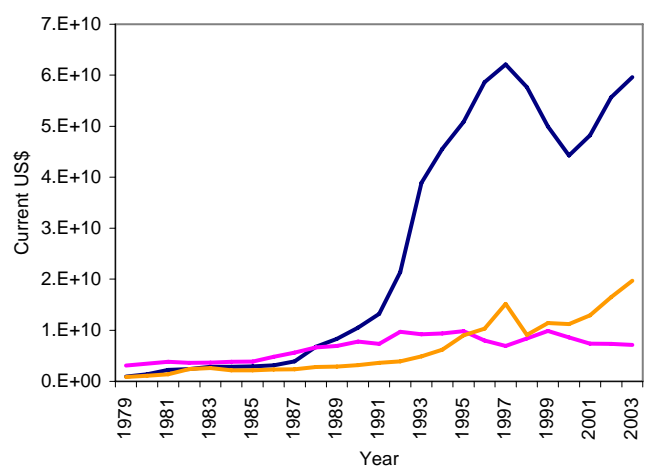

-FDI, net inflows (BoP, current US\$)

—ODA \& official aid (current US\$)

Worker remittances \& employee compensation, received (US\$)

Source: World Bank (2005a and 2005b)

Figure 7: Europe and Central Asia

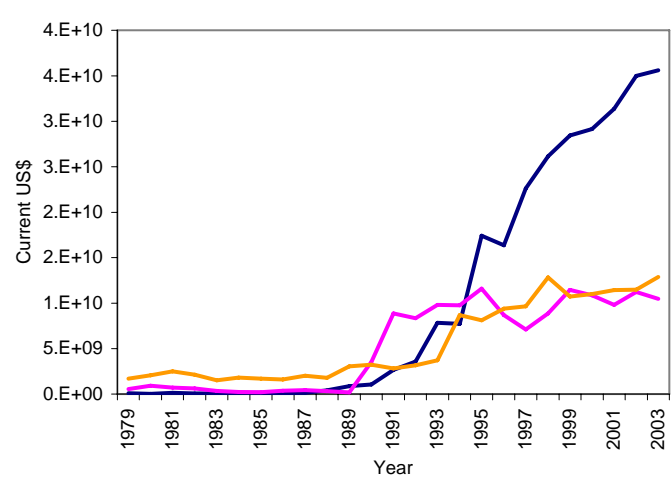

-FDI, net inflows (BoP, current US\$)

- ODA \& official aid (current US\$)

Worker remittances \& employee compensation, received (US\$)

Source: World Bank (2005a and 2005b)

Figure 9: South Asia

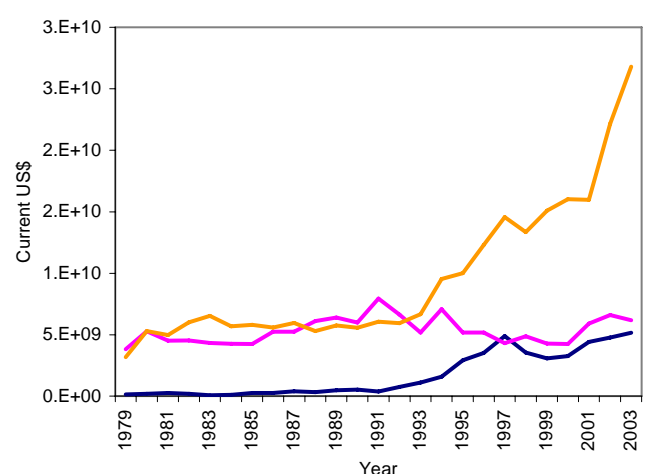

-FDI, net inflows (BoP, current US\$)

- ODA \& official aid (current US\$)

Worker remittances \& employee compensation, received (US\$)

Source: World Bank (2005a and 2005b)
Figure 6: Latin America and Caribbean

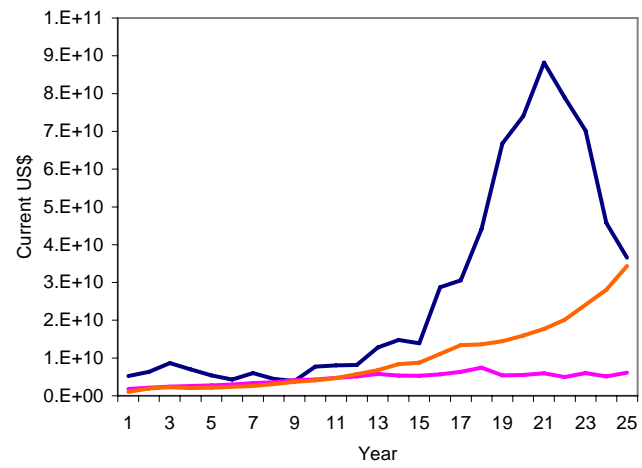

-FDI, net inflows (BoP, current US\$)

- ODA \& official aid (current US\$)

Worker remittances \& employee compensation, received (US\$)

Source: World Bank (2005a and 2005b)

Figure 8: Middle East and North Africa

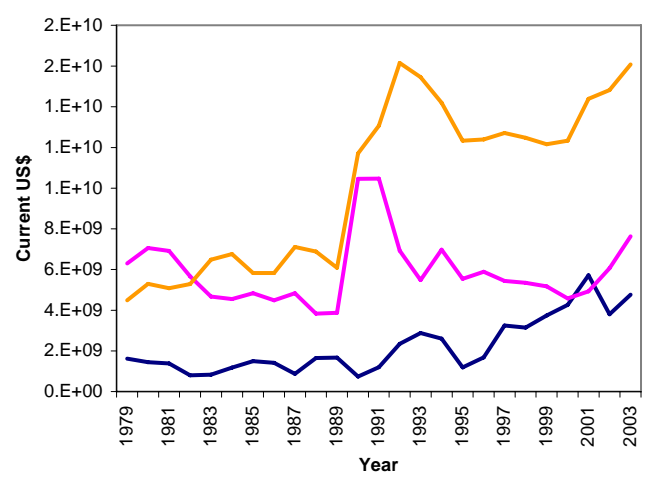

-FDI, net inflows (BoP, current US\$)

— ODA \& official aid (current US\$)

Worker remittances \& employee compensation, received (US\$)

Source: World Bank (2005a and 2005b)

Figure 10: Sub-Saharan Africa

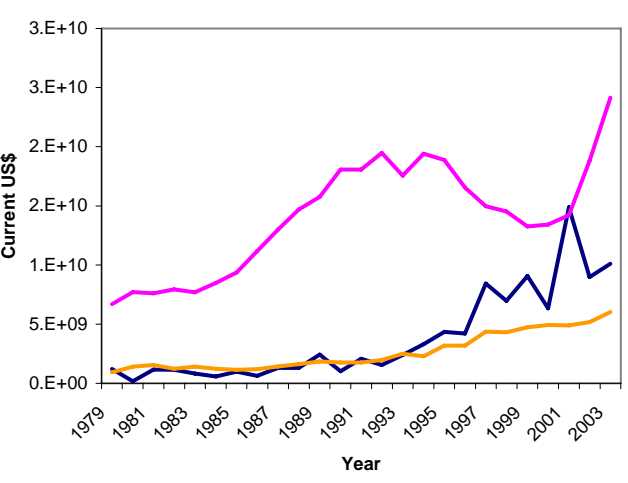

—FDI, net inflows (BoP, current US\$)

ODA \& official aid (current US\$)

Worker remittances \& employee compensation, received (US\$)

Source: World Bank (2005a and 2005b) 
In the low-income countries (Figure 4), remittances even now constitute the most important inflow, with ODA second in magnitude. The same pattern can be observed in the Middle East (Figure 8) and South Asia (Figure 9). In Sub-Saharan Africa, ODA flows dwarf both FDI and workers' remittances (Figure 10) and remittances are the least important inflow only in this region, but even here there is a steady increase.

The accuracy of the data presented above may vary among regions. There is considerable variation in how remittances are transferred through formal or informal channels, a fact which affects whether or not flows are recorded (for an overview of the players in the remittance market, see Orozco 2004). The Global Economic Prospects report 2006 (World Bank 2005c) provides an overview of the different channels used for remittances at the country level. This varies from formal channels being used in the Dominican Republic in 96 per cent of the cases to just 20 per cent in Uganda (World Bank 2005c: 91, based on World Bank household surveys). In Sub-Saharan Africa, for example, the use of informal channels is more widespread, and thus is not well recorded (Sander 2003: 3-4). The current state of data on remittances is disadvantaged by this large variation in the channels used, and should be kept in mind.

By matching migration patterns worldwide, Harrison, Birrton and Swanson (2003) estimate the size of remittance flows for each continent and for selected countries (origin and destination) for the year 2000.1 Table 1 shows the aggregate per continent. Remittances flows from North America to Latin America and the Caribbean are large at US\$14.2 billion, but remittance flows between Asian countries are twice that size, displaying a large south-south remittance flow in Asia (within-Asia flows are US\$29.3 billion if Japan is excluded). Remittance flows within Africa are estimated to be larger than those from both Europe and Asia. Other large magnitudes are directed from North America to Asia and within Europe.

Table 1

Size of remittance flows between continents (2000)

\begin{tabular}{lccccccc}
\hline \multicolumn{7}{c}{ Remittances going to: } \\
\cline { 2 - 7 } & Africa & Asia & Europe & LAC & North America & Oceania & Total (a \\
\hline Remittances coming from: & & & & & & & \\
Africa & 3.7 & 0.5 & 0.1 & 0.0 & 0.0 & 0.0 & 4.2 \\
Asia & 3.4 & 31.5 & 3.4 & 0.5 & 0.2 & 0.0 & 39.0 \\
Europe & 2.6 & 3.2 & 9.5 (b & 0.4 & 0.4 & 0.1 & 16.2 \\
Latin America/Caribbean & & 0.1 & 0.6 & 1.1 & 0.1 & 0.1 & 29.6 \\
North America & 0.7 & 7.9 & 5.7 & 14.2 & 0.9 & 0.1 & 0.8 \\
Oceania & 0 & 0.2 & 0.4 & & 0 & 0.1 & 91.5 \\
& 10.4 & 43.4 & 19.6 & 16.2 & 1.6 & 0.3 & 9 \\
\hline
\end{tabular}

Notes: (a Totals may differ slightly in own calculations due to rounding.

(b US\$24.1 million for European border-workers excluded.

Source: Harrison, Britton and Swanson (2003).

1 The data by Harrison, Britton and Swanson (2003) are not an exact match to the year 2000 data by the World Bank (2005b). Although categorized somewhat differently, Latin America-Caribbean flows reported here are smaller, while European and Asian flows larger. Although both sets are based on the IMF balance-of-payment statistics, they have been augmented with the authors' own estimates for missing or badly recorded flows. This difference is a good indication of the need for improvements in remittance data. 
When we look more closely at the flows within regions, they are not evenly distributed among countries. Table 2 gives more detail by listing all remittance flows in 2000 that exceeded US\$300 million (Harrison, Birron and Swanson 2003). The flow from the US to Mexico is overwhelmingly the largest, accounting for about half of all flows to LAC countries. The table also shows that remittance flows within Asia originate largely in Saudi Arabia, with Japan in second place. More than half of the Europe-to-Asia flows occur within the Germany-Turkey corridor. Although the largest flows are to developing countries, some developed countries also receive considerable amounts of remittances (Canada, Germany, UK and Italy). The sending countries are all developed OECD countries, with the exception of Saudi Arabia (developed, but not OECD). Despite these large flows originating in the developed countries, about 30 per cent of all remittance flows are 'south-south' flows (if Saudi Arabia were classified as a developing country, this would raise south-south remittances to 45 per cent, World Bank 2005c: 111).

Table 2

Largest remittance corridors in 2000 in decreasing order

\begin{tabular}{|c|c|c|}
\hline From & To & Amount (US\$ million) \\
\hline United States & Mexico & $7,612.5$ \\
\hline Saudi Arabia & India & $3,609.7$ \\
\hline Saudi Arabia & Pakistan & $1,804.9$ \\
\hline Saudi Arabia & Philippines & 1.582 .7 \\
\hline Saudi Arabia & Egypt & $1,388.4$ \\
\hline United States & China & $1,350.5$ \\
\hline Germany & Turkey & $1,195.2$ \\
\hline United States & Philippines & $1,186.4$ \\
\hline Japan & Korea & $1,012.1$ \\
\hline United States & India & 977.7 \\
\hline Saudi Arabia & Indonesia & 971.8 \\
\hline United States & Vietnam & 837.9 \\
\hline Saudi Arabia & Bangladesh & 694.2 \\
\hline France & Portugal & 659.2 \\
\hline United States & Canada & 658.2 \\
\hline United States & Germany & 634.0 \\
\hline France & Morocco & 600.1 \\
\hline United States & United Kingdom & 595.1 \\
\hline France & Algeria & 568.5 \\
\hline Japan & China & 534.6 \\
\hline Switzerland & Italy & 448.4 \\
\hline United States & Italy & 437.9 \\
\hline United States & Poland & 432.0 \\
\hline United States & Colombia & 422.3 \\
\hline Japan & Brazil & 405.3 \\
\hline Germany & Italy & 370.2 \\
\hline United States & Russia & 353.4 \\
\hline
\end{tabular}

Source: Harrison, Britton and Swanson (2003). 
It is often claimed that remittance flows are more stable than other capital inflows. Using the World Development Indicators (WDI) 2005 (World Bank 2005b) for developed countries as a whole, we calculate and compare the volatility of remittance flows, ODA and FDI over the period 1979-2003, measuring volatility in two ways. One is the coefficient of variation, calculated as the standard deviation divided by the mean (times 100). The coefficients of variation of the three capital flows indicate that the least volatile flow is ODA, followed by remittances, with FDI being the most volatile (Table 3).

This variable, however, does not take into account increasing trends in the data. Since FDI and remittances show an increasing trend during this period, we also want to measure volatility with a linear-trend assumption for each of the three capital flows. A steady increase in both remittances and FDI is therefore not included as part of volatility. We measure the best-fit trend line for the three capital flows, by regressing them individually against the period measured (per year), including a constant in the regression. We then calculate the standard deviation of the residuals of each regression as a measure of volatility (the square root of the sum of the squared residuals). Qualitatively this measure yields similar results as the coefficient of variation: ODA is the least volatile flow followed by remittances and FDI.

Table 3

Measures of volatility for FDI, ODA and remittances

\begin{tabular}{lccc}
\hline & FDI & ODA & Remittances \\
\hline Coefficient of variation & 95 & 32 & 65 \\
Std dev. of residuals of a linear regression line & $1.4 \mathrm{E}+11$ & $3.7 \mathrm{E}+10$ & $4.7 \mathrm{E}+10$ \\
\hline
\end{tabular}

Source: Own calculation based on data from World Bank (2005b).

\section{The effect of remittances on financial inclusion}

In this section we explore the exact channels in which changes that may cause remittances to increase financial inclusion are taking place. We look at demand, supply and policy factors, also applying the access frontier theory to financial markets in the developing countries.

\subsection{Demand factors}

Remittance senders, by definition, need at least one financial service: one that offers international payments. This demand can be an incentive for turning towards the banking sector or other financial institutions as a supplier. At the other end of the transaction, the need to receive remittances may induce people to look for the first time for financial services beyond their neighbourhood. The World Bank (2005c) notes that 'in contrast to cash transactions, remittances channelled through bank accounts may encourage savings and enable a better match for savings and investment in the economy'. Thus for many, migration and subsequent sending of remittance can be the first personal interaction with the global economy. 
The migrant sending the remittances induces the recipient to contact the institution through which the money is being transmitted. If this institution is a bank offering supplementary financial products (compared to a money transfer organization or informal channel that offers remittance-sending services only), this interaction can create a demand for products such as savings, credit, mortgages and insurance. In this manner, the increased financial awareness of the migrant can be the driving force for increased literacy at the receiving end. Estimates show that around 10 per cent of remittance receipts are saved, invested, and used for entrepreneurial activity (Orozco and Fedewa 2005: 4). The fact that some cash inflow is invested indicates that a demand for complementary financial products does exist among remittance receivers.

Some remittances are sent in-kind, in order to stipulate the use of the remitted 'capital'. This implies that there is a certain need on the sender's side to influence the use of their money (i.e., sending an airline ticket or vouchers). Linking other financial products, such as different payout options or mortgages, to the remitted amount is a service that is already at times requested by customers. Increasing the possibilities in this manner for formal money transfer services could be a response to the existing demand (Sander and Maimbo 2005: 68).

\subsection{Supply factors}

A wide array of institutions exists to respond to the vast demand for remittance-sending services. In addition to many informal channels and the money transfer organizations that capture a large share of the market, other more diversified and formal financial institutions also offer similar services. Commercial banks, recognizing the vast size of remittance flows 2 however small individual amounts may be, are increasingly interested in targeting this new market segment. Besides capturing money flows, the remittance channel can be used to sell financial service-packages geared towards low-income individuals. Hernández-Coss (2005) states that 'by developing formal remittance channels that are competitive with informal ones, the formal financial sector has an incentive to develop and benefit from the overall opportunity to grow and expand through the remittance market'. Credit unions worldwide have also focussed on remittances and have collectively created a remittance service (IRnet) for sending money electronically. In the process, they offer other financial services to these users such as savings accounts (see Grace 2005).

The perceived benefits of serving the low-income market have increased as a result of the demand by the poorer people for remittance services and the ensuing constant inflow of money. Regular remittances can reduce informational problems because the continual inflow of money from abroad allows the lower-income segment of the population to build a sound financial history with a financial institution. The earned income now needs some form of intermediation in order to transfer it to destination. Banks can cross-sell to obtain new clients and enable them to build a financial history by offering international transfer services together with complementary services, such as savings or checking accounts. Through the remittance inflow, the bank gets an insight into the client's income and expected future funds, thus indicating the potential

2 Harris (2002) estimates that the average annual amount per sender is in the range of US\$700-1,000 (quoted in Orozco 2003). 
creditworthiness of the recipient, since a constant (future) inflow can repay loans. In addition, as adverse circumstances at home generally increase remittances from abroad, 3 this can potentially lower a client's risk profile. Banks thus obtain information about prospective loan clients, reducing the problem of adverse selection. Furthermore, remittances are a relatively risk-free way of establishing contact with new clientele. 4 The bank can use this knowledge to base greater emphasis in its client analysis on 'soft' data, such as reliability and character of the firm's owner.

The argument is similar for remittance inflows as a marketable collateral. Remittance inflows have not only an informational function, but also convey direct value to the bank. When remittances go through a bank, clients can use both current and future inflows as 'collateral'. If the inflows are accepted by a bank as such, loans could be (partly) covered by remittance inflows, thus lowering the bank's risk, and motivating payback and optimal project management.

Finally, the direct income effect of remittances may affect supply. When a family member decides to migrate, he/she would, rationally speaking, do so only if the expected benefit from working abroad minus the extra costs of sustaining oneself abroad were larger than the family income before migration. Therefore, receiving families will in general move to a higher-income client group that is more attractive for the bank and may thus boost the supply of financial services for this group.

\subsection{The access frontier}

The access frontier can be applied to examine the relationship between remittance inflows and financial inclusion from a different angle. This method combines demand and supply arguments and is used by Porteous (2004) to look at how a financial market can 'work for the poor'. The access frontier can be defined as the maximum usage possible under existing structural conditions of technology, infrastructure and regulation (Porteous 2004: 8). He argues that the access frontier expands outward until market development moves into a saturation and consolidation phase, where the market reaches a natural limit. Usage is at its maximum, and non-usage becomes a genuine choice, unhindered by income or supply constraints. Porteous investigates why the access frontier in developing countries is not yet at its maximum (natural limit).

We take the example of South Africa, cited by Porteous, to demonstrate how remittance inflows can move the access frontier outwards. In South Africa, 48 per cent of adults have a bank account. The two most frequently cited reasons for not having a bank account are the lack of either a regular income (35.6 per cent) or a job (59.8 per cent). According to the third most common reason, earnings are too scant to make it worthwhile (11.4 per cent). One to 6 per cent of people cite reasons such as having no identity documentation, not qualifying for an account or not wanting to keep a minimum balance nor pay service fees.

The regular inflow of remittances may move the access frontier outwards by eliminating the reasons for non-usage. Remittance inflows can function as a substitution for a job or

3 For evidence on countercyclicality of remittance flows, see World Bank (2005c: 99-100).

4 See Berger and Udell (2002) on relationship lending. 
regular income. Since remittances in most cases are sent to sustain a family, the inflow is often regular, making it comparable to 'regular income'. Also, when a family member migrates, family earnings tend to increase, thereby reducing the income-effect problems of having a bank account. These make the recipients of remittances interesting clients for banks. If the obstacles to banking, whether demand or supply-led, are removed, the receipt of international remittances may trigger an outward move of the access frontier. Recipients become potential bank clients, and they themselves will also have greater need to use banking services.

The effects mentioned above will depend on the ability and willingness of banks to adapt. If banks are interested in remittance inflows from abroad, their product packages should be expanded accordingly, by offering, for example, low cost or free international transactions for clients who have a bank account with them. However, as Prahalad (2005: 8) notes, a dominant logic applies to private-sector businesses that may restrict their ability to see a dynamic and viable market opportunity at the 'bottom of the pyramid'. On the demand side, inadequate regulation and mistrust of banks can hinder the development of financial access considerably. Adequate government regulation and policy in this area will also play a role. These are discussed next.

\subsection{Policy and regulatory issues}

Through policy geared at integrating remittance senders into the formal economy, governments can create a more inclusive financial sector and a more efficient and formal economy. They can increase the financial depth of the economy and improve the monitoring of financial flows. Governments can influence access to formal financial services in a country by stimulating remittance sending through formal channels. This puts migrants and remittance recipients in touch with diversified financial institutions, and can lead to increased demand and supply of other financial products.

Governments can encourage transfers through formal channels by removing taxes on incoming remittances, relaxing exchange and capital controls, allowing domestic banks to operate overseas, providing ID cards for migrants, supporting hometown associations and providing matching grants, offering loan/pension schemes and bonds targeted at the diasporas, and by actively supporting the diaspora to help ensure the welfare of their citizens abroad (World Bank 2005c: 95). Also, educating the population on the benefits and processes of financial institutions can increase demand for formal financial services (World Bank 2003b). These measures make it more attractive for diversified financial institutions to enter the remittance market, and for the clientele to send money through formal channels. Two regulatory issues in moving towards formal channels need, however, to be highlighted: identification requirements for migrants and regulation on money laundering and terrorist financing.

Valid immigration status is often a problem in using formal channels to remit funds. Migrants without legal status lack adequate identification for opening bank accounts abroad or using the banking system to transfer funds. Surveys of migrants in Los Angeles and New York show that they are discouraged from opening bank accounts by the minimum balance requirements and strict identification regulations (Ratha 2003: 35 ). In these cases, migrants tend to resort to money transfer organizations or informal networks. With alternative, acceptable forms of identification for opening bank accounts, more migrants are able to participate in the formal banking system and use 
this channel to transfer money abroad. The most prominent example of this measure is the 'matrícula consular' issued to Mexican migrants at consulates in the US (Hernández-Coss 2005: 12). As private banks become more interested in the remittance market, they will increasingly start to accept identification other than those based on legal immigrant status. Much, however, depends on the immigration policy of the country. For security reasons, some authorities may disagree with this alternative form of identification, an issue related to the next topic.

Another factor driving the formalization of international capital flows is the increased regulations on money laundering and financing terrorist activities which received a boost after September 11th. The US Patriot Act stipulates that banks and other financial institutions should endeavour to 'know their customers', or to be able to identify and monitor everyone depositing or transferring money through them (de Vasconcelos 2005). The small remittance organizations in the US that maintained bank accounts where money was pooled from various individual sources for transfers abroad have discontinued these accounts because under the new regulation banks considered it too risky. This policy has almost certainly led to an increased demand for formal banking channels for remittances, particularly in those countries where measured inflows have doubled or even tripled between 2001 and 2003 (World Bank 2005c: 91).

\subsection{Preliminary evidence for a causal relationship}

Currently, the Inter-American Development Bank (2005) estimates that less than 10 per cent of remittance receivers have access to basic banking services, although this estimate varies widely among countries. Countries with a long migrant tradition, such as Portugal, Turkey and the Philippines, have developed financial institutions geared towards migrant populations, with banks capturing a large proportion of remittances. When people become bank clients at the receiving end, this affects the number of individuals who are bank clients in the home country, including returning migrants. Portuguese banks, for example, have developed full banking services in France, Germany and other emigrant destinations, thus encouraging emigrants to have bank accounts and use banking services (Orozco 2002: 14-5). The Turkish remittance market consists mostly of Turkish banks with efficient systems for transferring money to accounts maintained with headoffices in the homecountry (Orozco 2002: 17). In the Philippines, banks have about 71 per cent share of the remittance market (Philippines Census Bureau, quoted in Orozco 2002: 16). According to Orozco and Fedewa (2005), remittance recipients in selected Latin American countries are more likely to be banking individuals than non-recipients (Table 4).

The experience of credit unions affiliated with the World Council of Credit Unions (WOCCU) shows that on average 14 to 28 per cent of the non-members who

Table 4

Percentage of population with bank accounts (remittance recipients and non-recipients)

\begin{tabular}{lccccc}
\hline Year 2003 & Guatemala & Honduras & El Salvador & Mexico & Ecuador \\
\hline Recipients & $41 \%$ & $34 \%$ & $31 \%$ & $19 \%$ & $46 \%$ \\
Non-recipients & $17 \%$ & $16 \%$ & $19 \%$ & $16 \%$ & $34 \%$ \\
\hline
\end{tabular}

Source: Orozco and Fedewa (2005). 
approach these institutions requesting transfer services through their IR network end up opening an account (Maimbo and Ratha 2005: 9). Generally, credit unions are well equipped to serve the previously non-banking remittance senders and receivers because of their good rural locations (Maimbo and Ratha 2005: 10).

\subsection{Other factors affecting financial inclusion}

The recent research paper by Beck, Demirgüç-Kunt and Martinez Peria (2005) presents new indicators of banking sector penetration for 99 countries, both on access and use, and shows the correlation between data on access to finance and other variables at a cross-country level, using various proxies for branch penetration, ATM penetration, number of loans and deposits.

Beck, Demirgüç-Kunt and Martinez Peria (2005) observe a correlation between banking outreach and economic size, and with population density. More densely populated areas have a higher bank branch and ATM penetration; the relevance of the economic size of a country suggests that economies of scale play a role in banking services. Financial outreach, like financial development, is positively correlated with institutional quality. Effective credit information sharing also shows a correlation with increased banking penetration (outlets), though not necessarily with the number of loans.

The variable restrictions on bank activities is correlated negatively with branch penetration. The share of assets held by government-owned banks has a negative correlation with demographic branch and ATM penetration. The concentration ratio is positively associated with branch and ATM penetration and with deposit taking. Finally, the communication and transportation infrastructure indicators have a positive correlation with all indicators used for access to and use of banking services. One more variable added in this discussion is average income level, to control for the possibility that a higher level of development does not influence the results.

\section{Research design}

As mentioned in the introduction, we focus on the impact of remittances on financial inclusion in developing countries. The set of developing countries included in the sample is based on data availability. The variable with the poorest availability for developing countries is financial inclusion. Consequently, selection of the sample countries is almost entirely based on the data availability of this (dependent) variable. A few countries were later deleted due to lack of remittance data, the main independent variable in the analysis.

One pitfall in using a sample based on data availability is that countries with a failing or unorganized government may be underrepresented because of poor administrative systems. This would bias the sample towards developing countries with 'better' governments, thus possibly the higher-income developing countries. Comparing the sample to the country population indicated that there is, indeed, a slight underrepresentation of low-income countries (only 24 per cent of the low-income countries are included) and an overrepresentation of lower middle-income and upper middle-income countries (54 per cent and 50 per cent, respectively). The total sample 
consists of 41 per cent of all nations classified as developing countries according to the World Bank Atlas Classification (2005d).

The regional representation of developing countries also varies; only 21 per cent of Sub-Saharan African developing countries are represented as opposed to 70 per cent of those in European and Central Asia. Sub-Saharan Africa, Middle East-North Africa, and East Asia-Pacific regions are underrepresented, whereas Europe and Central Asia, Latin America and the Caribbean, and South Asia are overrepresented (Table 5).

Table 5

Regional representation in sample

\begin{tabular}{|c|c|c|c|}
\hline \multirow[b]{2}{*}{ Region } & \multicolumn{2}{|c|}{ No. of countries in: } & \multirow{2}{*}{$\begin{array}{c}\text { Proportion of } \\
\text { countries in sample }\end{array}$} \\
\hline & The sample & This region & \\
\hline Europe and Central Asia & 19 & 27 & 0.704 \\
\hline Latin America and Caribbean & 19 & 32 & 0.594 \\
\hline Sub-Saharan Africa & 10 & 48 & 0.208 \\
\hline South Asia & 5 & 8 & 0.625 \\
\hline East Asia and Pacific & 7 & 24 & 0.292 \\
\hline Middle East and North Africa & 4 & 14 & 0.286 \\
\hline TOTAL & 64 & 153 & 0.418 \\
\hline
\end{tabular}

Source: Author's calculations using World Bank Atlas Classification (World Bank 2005d).

\subsection{Data collection}

Data on remittance flows are expected to systematically underreport real flows due to lack of information on flows through informal channels and inaccurate reporting by government bodies. Estimates on informal flows vary widely, between 50-250 per cent of recorded flows (Freund and Spatafora 2005: 2). Thus, for a comparative analysis it is difficult to use data that include estimates of informal flows. 5 A project on remittances data led by the World Bank, IMF and the UN is currently underway to clearly define remittances and incorporate their measurement into worldwide household surveys (Hovinga 2005). To optimize the estimates of remittance flows, we are making a compromise between using a dataset that is most complete and most accurate. The balance-of-payments statistics of the IMF are the most commonly used data in this respect, and three categories are often compiled (see also Reinke and Patterson 2005):

i) Workers' remittances (credit); transfers by migrants living abroad for longer than one year;

ii) Employee compensation (credit); transfers by migrants abroad for less than one year;

iii) Migrant transfers (credit); money that migrants take back home when they return indefinitely.

5 For methods on measuring informal remittances, see also Hernández-Coss (2005) and World Bank (2003a). 
The first two are the most relevant for financial transfer services, since these flows are transmitted by means other than personal delivery. However, the distinction between these three categories is sometimes blurred in individual country reports to IMF. Some countries report the aggregate of all three categories under either worker remittances or employee compensation. Therefore, for comparability, the World Bank incorporates all three items together (World Bank 2005b; see Reinke and Patterson 2005 for more detail). Since this is a cross-country comparative study, we use the dataset created by the World Bank, which also has the advantage that it has augmented the IMF data with estimates of remittances for countries with incomplete or missing data. The World Bank has also compiled figures per region and per income level, which is useful for a descriptive analysis of remittance flows worldwide.

\subsection{Financial inclusion}

Until recently, measuring financial inclusion on a cross-country level meant using proxies that were arguably more reflective of financial development than financial inclusion (see, for example, Beck, Levine and Loayza 1999; Peachey and Roe 2004). The dataset from Beck, Demirgüç-Kunt and Martinez Peria (2005) introduces various indicators on the access to financial services, use of deposits and loans, average deposit and loan size and even predicted share of households with bank accounts. It provides a comprehensive country-level comparison for both developed and developing countries. To construct the predicted share of households with bank accounts, they use a smaller dataset from Claessens (2005) and Gasparini, Gutierrez and Porto (2005) on the share of households with bank accounts (Sba) and regress this on the log of deposit accounts per 100,000 people and log of average deposit account size in USD. Since this specific measure gives a direct indication of the usage of formal savings and transaction services (and not just banking penetration or number of loans/deposits), this seems to be the best indicator to use for measuring the utilization of financial services, and is therefore applied here.

Opting for this variable also determines the time dimension to be used. The timeframe is just one year per country, allowing for a cross-sectional analysis only. Most data points are from 2003, though the years of data collection range from 2001 to 2005.

\subsection{Measuring other variables}

We include all factors that Beck, Demirgüç-Kunt and Martinez Peria (2005) show as correlating with at least one proxy for financial access and/or use (see section 3). As mentioned, we also include income level (GDP per capita) to control for income effects that may influence access to finance. The indicators used to measure these variables are listed in the Appendix, where we also present descriptive statistics of the dependent and independent variables (Appendix Table A1).

Since we are looking for a causal effect of remittance inflows on financial inclusion, a time lag is built into the analysis, by including statistics for each country on remittances for the year preceding the financial inclusion data. This way, if a relationship is found, it is less likely to flow in the opposite direction. Thus, data for financial inclusion stem from the years 2001-05 and for remittances from 2000-03 (data from 2004 are not yet available). To be comparable across countries, remittance flows are computed per 
capita, using population figures from the World Development Indicators (World Bank 2005b).

\section{Regression results}

In order to test the effect of remittance inflows on financial inclusion, we use the general to specific approach. We start with a model in which all independent variables are included. This model is specified as follows:

$$
\begin{aligned}
& \text { FININCL }=\beta_{1}+\beta_{2}(\text { LOG }) \text { REMCAP }+\beta_{3} \text { GOVERN }+\beta_{4} \text { POPDENS }+\beta_{5} \text { LOG } \\
& (\text { GDP })+\beta_{6} \text { GDPCAP }+\beta_{7} \text { COMINFR }+\beta_{8} \text { TRANSINFR }+\beta_{9} \text { CONCENTR }+\beta_{10} \\
& \text { CREDITINFO }+\beta_{11} \text { SHAREGOV }+\beta_{12} \text { RESTRICT }+\beta_{13} \text { ENTRYREQ }+e_{t}
\end{aligned}
$$

\section{Abbreviations}

FININCL $=$ predicted share of households with bank accounts;

REMCAP $=$ remittance inflow per capita;

GOVERN = governance index;

POPDENS = population density;

GDP = gross domestic product;

GDPCAP = GDP per capita;

COMINFR = communication infrastructure;

TRANSINFR $=$ transportation infrastructure;

CONCENTR $=$ concentration ratio;

CREDITINFO = credit information index;

SHAREGOV $=$ share of assets in government-owned banks;

RESTRICT $=$ restrictions on bank activities; and

ENTRYREQ = requirements for entry into banking.

Appendix Table A2 gives the definitions, sources and the year of observation for all variables.

Next, we delete all insignificant variables one at a time, and end up with explanatory variables that have a significance level below 10 per cent. In order to examine the robustness of the outcomes, for the preferred equation we present also an estimate in which data for certain developed economies are included.

A matter of concern may be the possible collinearity between the independent variables. Therefore, in Appendix Table A3, a correlation matrix for all independent variables is presented. This table shows that remittances per capita have no correlation with other variables higher than 0.27 (with population density). Looking at all the variables, none of the pairwise correlations is larger than 0.8 , indicating that there are no potentially harmful collinear relationships. We also create an auxiliary regression with remittances per capita on the left-hand side and all the other independent variables on the right. The $\mathrm{R}^{2}$ obtained is 0.28 (adjusted $\mathrm{R}^{2}$ is -0.0075 ). We can therefore conclude that the 
variation in remittances per capita is not explained by variation in the other variables. Thus, collinearity does not have a harmfully effect on the outcomes of the regressions.

We use two estimation techniques. First, we apply the ordinary least squares estimation method. Second, since it is well-known that least squares estimation results may be very sensitive to some possible outliers especially for small samples, we also use the median

Table 6

Explaining the predicted share of households with bank accounts

\begin{tabular}{|c|c|c|c|c|c|c|c|c|c|}
\hline & & $1 a$ & $1 b$ & & $2 a$ & $2 b$ & & $3 a$ & $3 b$ \\
\hline Constant & $\begin{array}{l}-0.22 \\
(0.86)\end{array}$ & & $\begin{array}{l}-0.39 \\
(0.00)\end{array}$ & $\begin{array}{l}-0.393 \\
(0.22)\end{array}$ & & $\begin{array}{l}-0.098 \\
(0.78)\end{array}$ & $\begin{array}{l}-0.364 \\
(0.21)\end{array}$ & & $\begin{array}{l}-0.691 \\
(0.01)\end{array}$ \\
\hline Lremcap & $\begin{array}{l}0.098 \\
(0.08)\end{array}$ & {$[0.74]$} & $\begin{array}{c}0.057 \\
(0.00)\end{array}$ & $\begin{array}{l}0.052 \\
(0.01)\end{array}$ & [0.42] & $\begin{array}{c}0.046 \\
(0.00)\end{array}$ & $\begin{array}{l}0.052 \\
(0.00)\end{array}$ & {$[0.27]$} & $\begin{array}{c}0.058 \\
(0.00)\end{array}$ \\
\hline Concentr & $\begin{array}{l}-0.209 \\
(0.54)\end{array}$ & {$[-0.18]$} & $\begin{array}{c}0.123 \\
(0.00)\end{array}$ & & & & & & \\
\hline Cominfr & $\begin{array}{l}0.476 \\
(0.49)\end{array}$ & {$[0.24]$} & $\begin{array}{l}0.193 \\
(0.00)\end{array}$ & & & & & & \\
\hline Creditinfo & $\begin{array}{l}0.012 \\
(0.64)\end{array}$ & {$[0.11]$} & $\begin{array}{c}0.004 \\
(0.00)\end{array}$ & & & & & & \\
\hline Entryreq & $\begin{array}{l}-0.04 \\
(0.43)\end{array}$ & {$[-0.25]$} & $\begin{array}{l}-0.06 \\
(0.00)\end{array}$ & & & & & & \\
\hline Lgdp & $\begin{array}{l}0.019 \\
(0.70)\end{array}$ & {$[0.15]$} & $\begin{array}{c}0.032 \\
(0.00)\end{array}$ & $\begin{array}{l}0.022 \\
(0.07)\end{array}$ & {$[0.19]$} & $\begin{array}{c}0.011 \\
(0.46)\end{array}$ & $\begin{array}{l}0.022 \\
(0.06)\end{array}$ & {$[0.14]$} & $\begin{array}{c}0.034 \\
(0.00)\end{array}$ \\
\hline Gdppc & $\begin{array}{l}0.000016 \\
(0.84)\end{array}$ & [0.13] & $\begin{array}{l}-4.5 e-06 \\
(0.00)\end{array}$ & & & & & & \\
\hline Govern & $\begin{array}{l}0.166 \\
(0.34)\end{array}$ & {$[0.44]$} & $\begin{array}{c}0.072 \\
(0.00)\end{array}$ & $\begin{array}{l}0.244 \\
(0.00)\end{array}$ & [0.63] & $\begin{array}{c}0.244 \\
(0.00)\end{array}$ & $\begin{array}{l}0.268 \\
(0.00)\end{array}$ & [0.73] & $\begin{array}{c}0.254 \\
(0.00)\end{array}$ \\
\hline Popdens & $\begin{array}{l}0.00004 \\
(0.89)\end{array}$ & {$[0.05]$} & $\begin{array}{l}-0.0002 \\
(0.00)\end{array}$ & & & & & & \\
\hline Restrict & $\begin{array}{l}-0.013 \\
(0.71)\end{array}$ & {$[-0.07]$} & $\begin{array}{c}0.007 \\
(0.00)\end{array}$ & & & & & & \\
\hline Sharegov & $\begin{array}{l}0.00012 \\
(0.96)\end{array}$ & {$[0.01]$} & $\begin{array}{l}-0.00047 \\
(0.00)\end{array}$ & & & & & & \\
\hline Transinfo & $\begin{array}{l}1.190 \\
(0.64)\end{array}$ & {$[0.16)$} & $\begin{array}{l}2.859 \\
(0.00)\end{array}$ & & & & & & \\
\hline $\mathrm{N}$ & 22 & & 22 & 37 & & 37 & 47 & & 47 \\
\hline Adj $R^{2}$ & 0.28 & & & 0.51 & & & 0.80 & & \\
\hline Pseudo $R^{2}$ & & & 0.51 & & & 0.42 & & & 0.63 \\
\hline $\mathrm{F}$ & $\begin{array}{l}6.92 \\
(0.003)\end{array}$ & & & $\begin{array}{l}24.70 \\
(0.00)\end{array}$ & & & $\begin{array}{l}61.90 \\
(0.00)\end{array}$ & & \\
\hline Skewness & -0.044 & & & 0.638 & & & 0.625 & & \\
\hline Kurtosis & 2.32 & & & 5.599 & & & 5.44 & & \\
\hline Rest test & $\begin{array}{l}F=0.15 \\
(0.93)\end{array}$ & & & $\begin{array}{l}F=0.76 \\
(0.52)\end{array}$ & & & $\begin{array}{l}F=1.16 \\
(0.34)\end{array}$ & & \\
\hline Method & OL & & MED & & OLS & MED & & LS & MED \\
\hline
\end{tabular}

Note: Figures in parentheses are p-values, based on White adjusted standard errors. Figures in brackets are standardized coefficients. Dependent variable is the predicted share of bank accounts (Sba). The sample for Equations 1 and 2 contains developing countries only. For Equation 3 we also added some (total of ten) developed economies for which data on the dependent and independent variables are available. OLS refers to the results from ordinary least squares regressions. MED refers to results from the quantile (median) regression technique. 
estimator. Median regressions are much more resistant to possible outliers. The median estimator essentially forms a part of the non-parametric quantile regression technique. This technique determines the coefficients by minimizing the sum of absolute deviations. More specifically, the median linear regression parameters are given by the value of the vector $\beta$ that minimizes $\sum_{i=1}^{n}\left|y_{i}-x_{i}^{\prime} \beta\right|=\sum_{i=1}^{n}\left(0.5-1\left(y_{i} \geq x_{i}^{\prime} \beta\right)\right)\left(y_{i}-x_{i}^{\prime} \beta\right)$. All estimates are done with STATA. The regression results are given in Table 6.

The table shows that in all cases, remittances have a significantly positive effect on financial inclusion. Including all potentially relevant variables, and estimating with OLS, remittances per capita become the only significant variable, at a 10 per cent level. When the median regression technique is used, remittances are significant at the 1 per cent level. Moreover, with this technique, all other variables appear to be significant as well. With a backward selection, remittances per capita enter significantly into the equation at a 1 per cent level, together with GDP at a 10 per cent level and the governance index at a 1 per cent level. The same results hold for the median regressor; now, however, GDP is no longer significant at the usual significance level.

When certain developed countries are included, remittances still appear to have a positive significant effect on financial inclusion, both in the OLS and the median estimator. When looking at the significance of the models as a whole, all models have a significant $\mathrm{F}$-value. The adjusted $\mathrm{R}^{2}$ varies between 0.28 and 0.8 . The regression results also indicate that in some cases (see, for instance, Equation 2a) the residuals are not normally distributed, indicated by the values for the Kurtosis and skewness. In these cases, the median estimator may be more reliable. The Ramsey reset test suggests that the equations are correctly specified, and that the functional form of the models is appropriate. Overall, the regression results clearly show the relevance of remittances in explaining financial inclusion.

\subsection{Remittances, financial inclusion and economic growth}

Although examination of the remittances-financial inclusion/economic growth nexus is not the main objective of this paper, we end this section by presenting some new evidence on the topic. We assess the impact of remittances on the economic growth of developing countries by estimating a set of equations in which per capita economic growth and financial inclusion are the endogenous variables. The results are presented in Table 7.

Table 7 clearly shows that financial inclusion positively affects per capita growth. In all regressions our indicator for financial inclusion has a positive and significant impact on growth. Moreover, also in this set of system regressions, remittances have a significantly positive effect on financial inclusion. We tried several other specifications of the growth equation, by also introducing remittances directly in the growth equation. However, in none of these specifications do the additional variables appear to be significant. For reasons of space, these regression results are not presented. Most importantly, the regressions given in Table 7 empirically confirm our main hypothesis that remittances stimulate financial inclusion and, through this channel, stimulate per capita growth. 
Table 7

Remittances, financial inclusion and per capita growth

\begin{tabular}{|c|c|c|c|c|c|c|c|c|}
\hline & $1 a$ & $1 b$ & $2 a$ & $2 b$ & $3 a$ & $3 b$ & $4 a$ & $4 b$ \\
\hline Dep. var. & Grow & Sba & Grow & Sba & Grow & Sba & Grow & Sba \\
\hline Lgdppc & $\begin{array}{l}-0.005 \\
(0.37)\end{array}$ & & $\begin{array}{l}-0.005 \\
(0.25)\end{array}$ & & $\begin{array}{l}-0.006 \\
(0.21)\end{array}$ & & $\begin{array}{l}-0.005 \\
(0.29)\end{array}$ & \\
\hline Govc & $\begin{array}{l}-0.013 \\
(0.01)\end{array}$ & & $\begin{array}{l}-0.0012 \\
(0.01)\end{array}$ & & $\begin{array}{l}-0.0012 \\
(0.01)\end{array}$ & & $\begin{array}{l}-0.0012 \\
(0.01)\end{array}$ & \\
\hline Trade & $\begin{array}{l}-1.4 e-06 \\
(0.99)\end{array}$ & & & & & & & \\
\hline Invgdp & $\begin{array}{l}0.0002 \\
(0.61)\end{array}$ & & $\begin{array}{l}0.00026 \\
(0.52)\end{array}$ & & & & & \\
\hline Sba & $\begin{array}{r}0.077 \\
(0.10)\end{array}$ & & $\begin{array}{c}0.059 \\
(0.03)\end{array}$ & & $\begin{array}{c}0.064 \\
(0.01)\end{array}$ & & $\begin{array}{r}0.061 \\
(0.01)\end{array}$ & \\
\hline Concentr & $\begin{array}{c}0.02 \\
(0.10)\end{array}$ & & $\begin{array}{c}0.018 \\
(0.11)\end{array}$ & & $\begin{array}{c}0.198 \\
(0.08)\end{array}$ & & $\begin{array}{c}0.019 \\
(0.084)\end{array}$ & \\
\hline Govern & $\begin{array}{l}-0.006 \\
(0.42)\end{array}$ & $\begin{array}{l}0.257 \\
(0.00)\end{array}$ & & $\begin{array}{c}0.263 \\
(0.10)\end{array}$ & & $\begin{array}{l}0.265 \\
(0.00)\end{array}$ & & $\begin{array}{c}0.244 \\
(0.00)\end{array}$ \\
\hline Lremcap & & $\begin{array}{c}0.055 \\
(0.00)\end{array}$ & & $\begin{array}{l}0.055 \\
(0.00)\end{array}$ & & $\begin{array}{c}0.055 \\
(0.00)\end{array}$ & & $\begin{array}{c}0.051 \\
(0.00)\end{array}$ \\
\hline Lgdp & & $\begin{array}{c}0.028 \\
(0.06)\end{array}$ & & $\begin{array}{c}0.026 \\
(0.10)\end{array}$ & & $\begin{array}{c}0.027 \\
(0.09)\end{array}$ & & $\begin{array}{c}0.029 \\
(0.03)\end{array}$ \\
\hline Grow & & $\begin{array}{l}-1.80 \\
(0.64)\end{array}$ & & $\begin{array}{l}-2.88 \\
(0.48)\end{array}$ & & $\begin{array}{l}-2.74 \\
(0.51)\end{array}$ & & \\
\hline Constant & $\begin{array}{c}0.030 \\
(0.40)\end{array}$ & $\begin{array}{c}-0.52 \\
(-1.27)\end{array}$ & $\begin{array}{c}0.037 \\
(0.22)\end{array}$ & $\begin{array}{l}-0.452 \\
(0.26)\end{array}$ & $\begin{array}{c}0.044 \\
(0.13)\end{array}$ & $\begin{array}{l}-0.471 \\
(0.24)\end{array}$ & $\begin{array}{c}0.039 \\
(0.18)\end{array}$ & $\begin{array}{l}-0.563 \\
(0.10)\end{array}$ \\
\hline $\mathrm{N}$ & 35 & 35 & 35 & 35 & 35 & 35 & 35 & 35 \\
\hline $\mathrm{R}^{2}$ & 0.39 & 0.49 & 0.41 & 0.42 & 0.40 & 0.43 & 0.40 & 0.58 \\
\hline
\end{tabular}

Notes: The sets of equations ( $1 \mathrm{a}$ and $1 \mathrm{~b} ; 2 \mathrm{a}$ and $2 \mathrm{~b}$; $3 \mathrm{a}$ and $3 \mathrm{~b}$ ) are estimated with three-stage least squares. P-values are in parentheses. Grow refers to the average GDP per capita growth rate of the 1990-2003 period. Sba refers to the percentage share of bank accounts (financial inclusion). Lgdppc is the initial value (1990) of GDP per capita. Govc is government consumption over GDP; trade is net trade over GDP and Invgdp is investment over GDP. The last three variables refer to 1999 and are derived from World Bank (2005b).

\section{Conclusions}

In this paper, we focus on the relationship between remittance inflows and financial inclusion in developing countries. We present single equation estimates on remittances and financial inclusion and system estimates in which economic growth is explained by, financial inclusion, for example, and financial inclusion by remittances inflows, for example. These regressions clearly confirm our main hypothesis that remittances have a development impact through their effect on financial inclusion.

Overall, our paper indicates the importance of studying the effects of remittances in developing countries. Remittances in terms of size are not only one of the main capital inflows in developing countries - often even more substantial than ODA-but also seem to have a robust positive effect on economic growth. It is therefore surprising that empirical studies on remittances inflows lag behind, certainly when compared to the numerous studies dealing with the development impact of ODA. 
We realize that more research is needed for a conclusive answer on the development impact of remittances. A drawback of our study - as well as of all other studies available - is that remittances data are still very limited. Therefore, data on remittance flows need to be improved and a method of recording remittance at the international level to be developed. From an academic point of view, quality data on remittances are essential for providing good policy guidance. Only then can the effects of remittance flows (not just on financial inclusion) be investigated more accurately. Measurement of informal flows in particular should be researched further, as is already happening (Reinke and Patterson 2005; Freund and Spatafora 2005). It would be interesting to analyse further what factors affect the use of formal as opposed to informal channels, since flows through formal channels are more likely to impact financial inclusion in a positive way. Also, the measure of financial inclusion needs to be improved. Building on the dataset created by Beck, Demirgüç-Kunt and Martinez Peria (2005), the next step could be to create variables that measure access to and usage of financial services across the board, not just with regard to deposits and loans. In addition, research could also be further improved by including other characteristics of the sending migrants into the analysis, such as income level since this is likely to play a role in the effect of remittances on financial usage. This would give better insight into the categories of migrants who are banking, who become banking individuals because of remittances, and who still do not use any formal financial services. Policy can then be focused on the groups who are yet to become banking individuals. 


\section{References}

Beck, T., R. Levine, and N. Loayza (1999). 'Finance and the Sources of Growth'. WB Policy Research Working Paper No. 2057. Washington, DC: World Bank.

Beck, T., A. Demirgüç-Kunt, and R. Levine (1999). 'A New Database on Financial Development and Structure'. WB Policy Research Working Paper No. 2146. Washington, DC: World Bank.

Beck, T., A. Demirgüç-Kunt, and M. Martinez Peria (2005). 'Reaching Out: Access to and Use of Banking Services Across Countries'. Washington, DC: World Bank.

Berger, A. N., and G. F. Udell (2002). 'Small Business Credit Availability and Relationship Lending: the Importance of Bank's Organizational Structure'. The Economic Journal, 112 (February): F32-F53.

Bugamelli, M., and F. Paternò (2005). 'Do Workers' Remittances Reduce the Probability of Current Account Reversals?'. WB Policy Research Working Paper No. 3766. Washington, DC: World Bank.

Chami, R., C. Fullenkamp, and S. Jahjah (2005). 'Are Immigrant Remittance Flows a Source of Capital for Development?'. IMF Staff Papers, 52 (1). Washington, DC: IMF.

Claessens, S. (2005). 'Access to Financial Services: A Review of the Issues and Public Policy Objectives’. WB Policy Research Paper No. 3589. Washington, DC: World Bank.

Djankov, S., C. McLiesh, and A. Shleifer (2004). 'Private Credit around the World'. Working Paper. Cambridge, MA: Department of Economics, Harvard University.

Freund, C., and N. Spatafora (2005). 'Remittances: Transaction Costs, Determinants, and Informal Flows'. WB Policy Research Working Paper No. 3704. Washington, DC: World Bank.

Gasparini, L., F. Gutierrez, and G. Porto (2005). 'Finance and Credit Variables in Household Surveys of Developing Countries'. Washington, DC: World Bank. Mimeo.

Grace, D. (2005). 'Exploring the Credit Union Experience with Remittances in the Latin American Market'. In S. M. Maimbo and D. Ratha (eds), Remittances: Development Impact and Future Prospects. Washington, DC: World Bank, 160-73.

Harris, N. (2002). Thinking the Unthinkable: The Immigration Myth Exposed. New York: I. B. Tauris and Co.

Harrison, A., T. Britton, and A. Swanson (2003). 'Working Abroad: The Benefits Flowing from Nationals Working in other Economies'. Paper presented at the Round Table on Sustainable Development, 19 November. Paris: OECD

Hernández-Coss, R. (2005). 'A Proposed Framework to Analyze Informal Funds Transfer Systems'. In S. M. Maimbo and D. Ratha (eds), Remittances: Development Impact and Future Prospects. Washington, DC: World Bank, 244-74.

Hovinga, I. (2005). 'Presentation'. Paper presented at the United Nations' Expert Group Meeting on International Migration and Development. 6-8 July. New York: UN. 
Inter-American Development Bank (2005). News Release. Available at: www.iadb.org (accessed 17 November 2005).

Kaufman, D., A. Kraay, and M. Mastruzzi (2005). 'Governance Matters IV: Governance Indictors for 1996-2004'. WB Policy Research Paper No. 3630. Washington, DC: World Bank.

La Porta, R., F. Lopez-de-Silanes, A. Shleifer, and R. Vishny (1998). 'Law and Finance'. Journal of Political Economy, 106: 1113-55.

Levine, R. (2003). Finance and Growth: Theory, Evidence and Mechanisms. Minnesota: University of Minnesota and NBER.

Maimbo, S. M., and D. Ratha (2005). 'Remittances: Development Impact and Future Prospects'. In S. M. Maimbo and D. Ratha (eds), Remittances: Development Impact and Future Prospects. Washington, DC: World Bank, 1-16.

Orozco, M. (2002). 'Worker Remittances: The Human Face of Globalization'. Working paper commissioned by the Multilateral Investment Fund of the Inter-American Development Bank. Washington, DC: Inter-American Dialogue.

Orozco, M. (2003). 'Worker Remittances: An International Comparison'. Working Paper commissioned by the Multilateral Investment Fund of the Inter-American Development Bank. Washington, DC: Inter-American Dialogue.

Orozco, M. (2004). 'The Remittance Marketplace: Prices, Policy and Financial Institutions'. Pew Hispanic Center Report. Washington, DC: Pew Hispanic Center

Orozco, M., and R. Fedewa (2005). 'Leveraging Efforts on Remittances and Financial Intermediation'. Report commissioned by the Inter-American Development Bank. Washington, DC: Inter-American Dialogue.

Porteous, D. (2004). 'Making Financial Markets Work for the Poor'. Paper commissioned by FinMark Trust, 31 October. Available at: www.dfid.gov.uk/news/files/trade_news/adb-workshop-makingfinancial.pdf

Prahalad, C. K. (2005). The Fortune at the Bottom of the Pyramid. Upper Saddle River, NJ: Wharton School Publishing.

Ratha, D. (2003). 'Workers' Remittances: An Important and Stable Source of Development Finance'. In S. M. Maimbo and D. Ratha (eds), Remittances: Development Impact and Future Prospects. Washington, DC: World Bank, 19-52.

Reinke, J., and N. Patterson (2005). 'Remittances in the Balance of Payments Framework'. Paper presented at International Technical Meeting on Measuring Remittances, 24-25 January. Washington, DC: IMF.

Sander, C. (2003). 'Capturing a Market Share? Migrant Remittance Transfers and Commercialisation of Microfinance in Africa'. Paper prepared for the conference on Current Issues in Microfinance, 12-14 August. Johannesburg.

Sander, C., and S. M. Maimbo (2005). 'Migrant Remittances in Africa: A Regional Perspective'. In S. M. Maimbo and D. Ratha (eds), Remittances: Development Impact and Future Prospects. Washington, DC: World Bank, 53-80. 
Solimano, A. (2003). 'Remittances by Emigrants: Issues and Evidence'. Paper presented at the WIDER conference on Innovative Sources for Development Finance. 17-18 May. Helsinki.

Stahl, C. W., and F. Arnold (1986). 'Overseas Workers' Remittances in Asian Development'. International Migration Review, 20 (4): 899-925.

De Vasconcelos, P. (2005). 'Improving the Development Impact of Remittances'. Paper presented at United Nations' Expert Group Meeting on International Migration and Development, 6-8 July. New York.

World Bank (2003a) 'Informal Funds Transfer Systems in the APEC Region: Initial Findings and a Framework for Further Analysis'. Paper presented at Asian-Pacific Economic Cooperation Finance Ministers Meeting, 1-5 September. Washignton, DC.

World Bank (2003b). Global Development Finance 2003. Washington, DC: World Bank.

World Bank (2005a). Global Development Finance 2005 Washington, DC: World Bank.

World Bank (2005b). World Development Indicators 2005. Washington, DC: World Bank.

World Bank (2005c). Global Economic Prospects Report 2006: Economic Implications of Remittances and Migration. Washington, DC: World Bank.

World Bank (2005d). World Bank Atlas Classification. Available at: web.worldbank.org/WBSITE/EXTERNAL/DATASTATISTICS/0,,contentMDK:20 420458 menuPK:64133156 pagePK:64133150 piPK:64133175 theSite PK:239419,00.html

World Bank. Regulation and Supervision Database. Washington, DC: World Bank. 


\section{Appendix}

Appendix Table A1 Descriptive statistics of dependent and independent variables

Appendix Table A2 Definitions, sources and year of observation for all variables

Appendix Table A3 Pairwise correlation coefficients between all independent variables 
Appendix Table A1

Descriptive statistics of dependent and independent variables

\begin{tabular}{lcrrrrr}
\hline All variables & $\begin{array}{c}\text { Predicted share of } \\
\text { banking households }\end{array}$ & $\begin{array}{c}\text { Remittance } \\
\text { inflow/capita at t-1 }\end{array}$ & $\begin{array}{c}\text { Economic size } \\
\text { (GDP) }\end{array}$ & $\begin{array}{c}\text { Average income level } \\
\text { (GDP per capita) }\end{array}$ & $\begin{array}{c}\text { Governance } \\
\text { index }\end{array}$ & $\begin{array}{c}\text { Concentration } \\
\text { ratio }\end{array}$ \\
Mean & 0.2632 & 64.3109 & $96,500,000,000$ & 2217.7130 & -0.2227 \\
on bank activities
\end{tabular}

N

\begin{tabular}{|c|c|c|c|c|c|c|}
\hline & $\begin{array}{l}\text { Communication infrastructure } \\
\text { (telephone lines per capita) }\end{array}$ & $\begin{array}{l}\text { Transportation infrastructure } \\
\text { (railways per } \mathrm{km}^{2} \text { ) }\end{array}$ & $\begin{array}{l}\text { Population } \\
\text { density }\end{array}$ & $\begin{array}{l}\text { Share of assets in } \\
\text { government-owned banks }\end{array}$ & $\begin{array}{l}\text { Credit information } \\
\text { index }\end{array}$ & $\begin{array}{l}\text { Requirements for } \\
\text { entry into banking }\end{array}$ \\
\hline Mean & 0.1462 & 0.0173 & 116.7910 & 24.5957 & 3.1667 & 7.3617 \\
\hline Median & 0.1222 & 0.0081 & 72.2395 & 16.3000 & 3.5000 & 8.0000 \\
\hline Maximum & 0.4172 & 0.1229 & 1060.7000 & 80.000 & 6.0000 & 8.0000 \\
\hline Minimum & 0.0024 & 0.0000 & 3.0393 & 0.0000 & 0.0000 & 3.0000 \\
\hline Std dev. & 0.1102 & 0.0221 & 162.2590 & 24.5717 & 2.0433 & 0.9874 \\
\hline Skewness & 0.5388 & 2.6351 & 3.7558 & 0.7537 & -0.3475 & -2.1430 \\
\hline Kurtosis & 2.3671 & 11.4366 & 20.2196 & 2.2759 & 1.9326 & 9.1315 \\
\hline Jarque-Bera & 4.1645 & 239.1355 & 941.1710 & 5.3599 & 4.0558 & 109.5986 \\
\hline Probability & 0.1246 & 0.0000 & 0.0000 & 0.0686 & 0.1316 & 0.0000 \\
\hline Observations & 64 & 58 & 64 & 46 & 60 & 47 \\
\hline
\end{tabular}


Appendix Table A2

Definitions, sources and year of observation of all variables

\begin{tabular}{|c|c|c|c|}
\hline Variable & Definition & Source & Year \\
\hline $\begin{array}{l}\text { Demographic branch } \\
\text { penetration }\end{array}$ & $\begin{array}{l}\text { No. of bank branches per } \\
100,000 \text { people }\end{array}$ & $\begin{array}{l}\text { Beck, Demirgüç-Kunt } \\
\text { and Martinez Peria } \\
(2005)\end{array}$ & $\begin{array}{l}\text { varies by } \\
\text { country } \\
(2001-05)\end{array}$ \\
\hline $\begin{array}{l}\text { Geographic branch } \\
\text { penetration }\end{array}$ & No. of branches per $1,000 \mathrm{~km}^{2}$ & Ditto & Ditto \\
\hline $\begin{array}{l}\text { Demographic ATM } \\
\text { penetration }\end{array}$ & No. of ATMS per 100,000 people & Ditto & Ditto \\
\hline $\begin{array}{l}\text { Geographic ATM } \\
\text { penetration }\end{array}$ & No. of ATMS per $1,000 \mathrm{~km}^{2}$ & Ditto & Ditto \\
\hline Loan accounts p.c. & Average loan size/GDP p.c. & Ditto & Ditto \\
\hline Loan-income ratio & No. of loans per 1,000 people & Ditto & Ditto \\
\hline Deposit accounts p.c. & Average deposit size/GDP p.c. & Ditto & Ditto \\
\hline Deposit income ratio & No. of deposits per 1,000 people & Ditto & Ditto \\
\hline $\begin{array}{l}\text { Predicted household } \\
\text { share with bank account }\end{array}$ & $\begin{array}{l}\text { Calculated using data on share } \\
\text { of households with bank } \\
\text { accounts on the log of deposit } \\
\text { accounts per } 100,000 \text { and the } \\
\text { log of average deposit size } \\
\text { (US\$) }\end{array}$ & $\begin{array}{l}\text { Beck, Demirguç-Kunt } \\
\text { and Martinez Peria } \\
\text { (2005), with data from } \\
\text { Claessens (2005) and } \\
\text { Gasparini, Gutierrez and } \\
\text { Porto (2005) }\end{array}$ & Ditto \\
\hline $\begin{array}{l}\text { Remittance inflow p.c. } \\
\text { at } t-1\end{array}$ & $\begin{array}{l}\text { Remittance inflow/total } \\
\text { population } \\
\text { at } \mathrm{t}-1\end{array}$ & $\begin{array}{l}\text { WB }(2005 a) \text { for } \\
\text { remittances; WB } \\
(2005 b) \text { for developed } \\
\text { countries and for GDP }\end{array}$ & $\begin{array}{l}\text { Remittances } \\
\text { and } \\
\text { population at } \\
\mathrm{t}-1\end{array}$ \\
\hline Economic size & Gross domestic product & WB (2005b) & 2003 \\
\hline Average income level & GDP p.c. (constant 2000 US\$) & WB (2005b) & 2003 \\
\hline Governance index & $\begin{array}{l}\text { Average score of six governance } \\
\text { indicators, where high score } \\
\text { implies better governance }\end{array}$ & $\begin{array}{l}\text { Kaufman, Kraay and } \\
\text { Mastruzzi (2005) }\end{array}$ & 2004 \\
\hline Concentration ratio & $\begin{array}{l}\text { Assets of three largest banks as } \\
\text { a share of assets of all } \\
\text { commercial banks in the } \\
\text { system }\end{array}$ & $\begin{array}{l}\text { Fitch's bankscope } \\
\text { database in Beck, } \\
\text { Demirgüç and Levine } \\
\text { (1999) }\end{array}$ & 2003 \\
\hline Credit information index & $\begin{array}{l}\text { Scored on 0-6 scale, score } \\
\text { increasing with availability of } \\
\text { credit information }\end{array}$ & $\begin{array}{l}\text { Djankov, McLiesh and } \\
\text { Shleifer (2004), adopted } \\
\text { from La Porta et al. } \\
\text { (1998). }\end{array}$ & $\begin{array}{l}2005 \text { data; } \\
2003-04 \text { data } \\
\text { not available } \\
\text { online }\end{array}$ \\
\hline $\begin{array}{l}\text { Restrictions on bank } \\
\text { activities }\end{array}$ & $\begin{array}{l}\text { Sum of restrictions on banks } \\
\text { owning real estate, insurance, } \\
\text { securities and non-financial } \\
\text { firms }\end{array}$ & $\begin{array}{l}\text { World Bank Regulation } \\
\text { and Supervision } \\
\text { Database }\end{array}$ & 2001 \\
\hline $\begin{array}{l}\text { Entry requirements for } \\
\text { banking }\end{array}$ & $\begin{array}{l}\text { No. of requirements for banking } \\
\text { license }\end{array}$ & Ditto & 2001 \\
\hline $\begin{array}{l}\text { Share of assets in } \\
\text { government-owned } \\
\text { banks }\end{array}$ & $\begin{array}{l}\% \text { of banking system assets in } \\
\text { banks with } 50 \%+\text { share owned } \\
\text { by government }\end{array}$ & Ditto & 2001 \\
\hline $\begin{array}{l}\text { Communication } \\
\text { infrastructure }\end{array}$ & Telephone lines p.c. & WB (2005b) & $\begin{array}{l}\text { 2003; } 2002 \text { for } \\
\text { some }\end{array}$ \\
\hline $\begin{array}{l}\text { Transportation } \\
\text { infrastructure }\end{array}$ & Railways per sq km² & WB (2005b) & $\begin{array}{l}2002 \text { and } \\
2003\end{array}$ \\
\hline Population density & Total population/total land area & WB (2005B) & 2003 \\
\hline
\end{tabular}

Notes to Appendix Table A2 (next page) 
Notes to Appendix Table A2: Additional variables used in growth regressions:

Grow: GDP per capita growth rate between 1990-2003. Calculated from GDP per capita figures in constant 2000US\$ (source: WB (2005b).

Govc: Government consumption over GDP, 1999 (source: WB 2005b).

Invgdp: Gross investment over GDP, 1999 (source: WB 2005b).

Lgdp: $\quad$ Ln GDP per capita of 1990 (source: WB 2005b).

Trade: Net Trade over GDP, 1999 (source: WB 2005b).

Appendix Table A3

Pairwise correlation coefficients between all independent variables

\begin{tabular}{|c|c|c|c|c|c|c|}
\hline & COMINFR & CONCENTR & CREDITINFO & ENTRYREQ & GDP & GDPCAP \\
\hline COMINFR & 1.000000 & -0.099790 & 0.219836 & -0.040053 & 0.126198 & 0.731847 \\
\hline CONCENTR & -0.099790 & 1.000000 & -0.221936 & 0.096412 & -0.264003 & -0.023732 \\
\hline CREDITINFO & 0.219836 & -0.221936 & 1.000000 & -0.066661 & 0.072580 & 0.452804 \\
\hline ENTRYREQ & -0.040053 & 0.096412 & -0.066661 & 1.000000 & -0.207876 & -0.059795 \\
\hline GDP & 0.126198 & -0.264003 & 0.072580 & -0.207876 & 1.000000 & 0.043252 \\
\hline GDPCAP & 0.731847 & -0.023732 & 0.452804 & -0.059795 & 0.043252 & 1.000000 \\
\hline GOVERN & 0.540971 & 0.076189 & 0.425651 & -0.183370 & -0.013865 & 0.765663 \\
\hline POPDENS & -0.106434 & -0.177748 & -0.136680 & -0.220983 & 0.018302 & -0.053917 \\
\hline REMCAP & 0.111719 & 0.058276 & 0.024737 & 0.151785 & -0.149840 & 0.181374 \\
\hline RESTRICT & -0.097490 & 0.002701 & -0.057729 & -0.092019 & 0.287350 & -0.231934 \\
\hline SHAREGOV & 0.014680 & -0.204817 & -0.199169 & -0.183069 & 0.425331 & -0.176688 \\
\hline \multirow[t]{2}{*}{ TRANSINFR } & 0.621847 & -0.038677 & 0.032291 & 0.019170 & -0.051169 & 0.537903 \\
\hline & GOVERN & POPDENS & REMCAP & RESTRICT & SHAREGOV & TRANSINFR \\
\hline COMINFR & 0.540971 & -0.106434 & 0.111719 & -0.097490 & 0.014680 & 0.621847 \\
\hline CONCENTR & 0.076189 & -0.177748 & 0.058276 & 0.002701 & -0.204817 & -0.038677 \\
\hline CREDITINFO & 0.425651 & -0.136680 & 0.024737 & -0.057729 & -0.199169 & 0.032291 \\
\hline ENTRYREQ & -0.183370 & -0.220983 & 0.151785 & -0.092019 & -0.183069 & 0.019170 \\
\hline GDP & -0.013865 & 0.018302 & -0.149840 & 0.287350 & 0.425331 & -0.051169 \\
\hline GDPCAP & 0.765663 & -0.053917 & 0.181374 & -0.231934 & -0.176688 & 0.537903 \\
\hline GOVERN & 1.000000 & -0.111593 & -0.011880 & -0.156725 & -0.219176 & 0.382951 \\
\hline POPDENS & -0.111593 & 1.000000 & 0.267179 & 0.214463 & 0.202532 & 0.144333 \\
\hline REMCAP & -0.011880 & 0.267179 & 1.000000 & 0.068121 & -0.185363 & 0.113073 \\
\hline RESTRICT & -0.156725 & 0.214463 & 0.068121 & 1.000000 & 0.252075 & -0.091206 \\
\hline SHAREGOV & -0.219176 & 0.202532 & -0.185363 & 0.252075 & 1.000000 & 0.071678 \\
\hline TRANSINFR & 0.382951 & 0.144333 & 0.113073 & -0.091206 & 0.071678 & 1.000000 \\
\hline
\end{tabular}

Abbreviations: Same as in equation 1 